J. Asiat. Soc. Bangladesh, Sci. 44(1): 69-78, June 2018

\title{
EFFECTS OF PROBIOTICS ON GROWTH AND PRODUCTION OF MONOSEX TILAPIA (OREOCHROMIS NILOTICUS) IN NYLON NET CAGES AT DEKAR HAOR, SUNAMGANJ, BANGLADESH
}

\author{
P.DAS ${ }^{1}$, M. S. ISLAM ${ }^{1 *}$, M. BISWAS ${ }^{1}$, P. R. DAS ${ }^{2}$ AND A. S. M. ARIF ${ }^{2}$ \\ ${ }^{1}$ Department of Coastal and Marine Fisheries \\ Sylhet Agricultural University Sylhet, Bangladesh \\ ${ }^{2}$ Department of Aquaculture, Sylhet Agricultural University, \\ Sylhet, Bangladesh
}

\begin{abstract}
To assess the effect of probiotics on growth, survival rate and production performance of all monosex tilapia (Oreochromis niloticus) for a period of 120 days in 2016 in nylon net cages placed in Dekar haor of Sunamganj district. The study was categorized into four treatments as $\mathrm{T}_{1}$ (brand a), $\mathrm{T}_{2}$ (brand $\mathrm{b}$ ), $\mathrm{T}_{3}$ (brand c) and $\mathrm{T}_{4}$ (control) based on probiotics and each having three replicates. Cages were stocked with nursed male tilapia fry at a density of $35 \mathrm{nos} . / \mathrm{m}^{3}$ with average size of $14.33 \pm 6.41-16.33 \pm 3.15 \mathrm{~g}$. Tilapia of all the cages were fed with commercial mega floating feed at a decreasing rate of $10-5 \%$ of total biomass thrice daily. Feed was supplemented with probiotics at a rate of $0.5 \mathrm{~g} / \mathrm{kg}$. Comparatively higher growth $(307.33 \pm 33.92 \mathrm{~g})$, survival rate $(97.6 \pm 4.90 \%)$, yield $\left(10.5 \pm 1.15 \mathrm{~kg} / \mathrm{m}^{3}\right)$, net profit (Tk.798.96 $\left.\pm 90.85 / \mathrm{m}^{3}\right)$ and lower food conversion ratio (1.16) were secured in $T_{3}$ than that of other treatments, which were manifolds higher than the earthen freshwater and brackish waterbodies. Therefore, results of the study reveal that probiotics may be used in aquaculture for increasing fish production.
\end{abstract}

Key words: Probiotics, Cage farming, Growth performance, Survival rate, Production

\section{Introduction}

Fisheries sector plays a key role in the agro-based economy of Bangladesh. There are many haors (bowl shaped floodplains depression connected into canals and rivers with unique hydro-ecological characteristics) in Bangladesh. These are located in northeastern region of the country covering an area of 19,998 sq. km and accommodating 19.37 million people (MPHA 2012). These are also known as freshwater seas and act as a home of indigenous fishes and other aquatic biodiversity. Haor has a great contribution to national fisheries sector. It is a vital supplier of inland freshwater fisheries with a fishing area of $1,14,793$ ha. About $10 \%$ of the total population is directly or indirectly employed in fisheries sector. Fisheries of Bangladesh have enormous prospects and scope of

\footnotetext{
*Author for correspondence. Email: islamms2011@yahoo.com
} 
progression (DoF 2017). Tilapia (O. niloticus) are widely distributed in many countries of the world. Now it can be found in more than 100 countries (Ballarin and Hallar 1982).

Among different species of tilapia, Nile tilapia (O. niloticus) of monosex type are more suitable fish for cage culture. They do not breed/multiply, which make it easy for fish farmers to avoid uncontrolled breeding in their growing water-bodies. They grow fast and attain large size within a short period in pond, cage and pen than other tilapia species. Monosex tilapia become marketable size of 100 - $150 \mathrm{~g}$ within 2 - 3 months. Male tilapia grow significantly faster, larger and are more even in size than females (Ponzoni et al. 2005). This species is currently considered to be the most important and commonly cultured species around the world and constitutes over $70 \%$ of cultured tilapia (Fitzsimmons 2004) which represent approximately 6\% of total farmed fish production (FAO 2004). Size of tilapia is entirely dependent on the size of pond/cage/pen, natural productivity of water, feed quality, frequency of feeding, stocking density, size of fry/fingerlings and management.

Cage aquaculture is a rising technology to accelerate fish production. A widespread and profitable culture of fish and prawns in cages has already been developed successfully in Asia, Europe and America (Beveridge 1987). This practice in South-East Asia first started from late $1800 \mathrm{~s}$, since then, many countries are practicing cage culture in freshwater and marine environments including ponds, rivers, haors, beels, open sea, estuaries, lakes, reservoirs, etc. (Balcazar et al. 2006). Cage culture in open waterbodies like haor area could provide a prospect for increasing fish production, uplift of livelihood of rural fish farmers and mitigating protein demand in the nation.

Probiotics are feed additives defined as live beneficial bacteria that are found in nature and may serve as dietary supplements to improve the host intestinal microbial balance and growth performance (Gatesoupe 1999). Today, probiotics are quite common place in health promoting "functional foods" for human as well as therapeutic, prophylactic and growth supplements in animal production and human health (Geovanny et al. 2007).

Though probiotics of several brand names (Aqua photo, Aqua mazic, Ammonil, Safegut, Probio-Aqua, Super biotic, Super PS) in powder or liquid forms are found in the markets, most of the farmers do not know the techniques of use and impact of these probiotics. A few works have been done on probiotics in freshwater aquaculture and shrimp culture in brackishwater to determine the mode of application of Bacillus probiotics (Islam et al. 2008). But work related to use of probiotics in haor cage farming are not available in Bangladesh. Therefore, there is a need to understand the effect of probiotics in artificial diet used for tilapia cage culture in haor area. Keeping these in mind, the present research was undertaken aimed to evaluate the effect of probiotics on the production of monosex 
tilapia (O. niloticus) in cages and to develop farming system technique of tilapia cage culture in open waterbody.

\section{Materials and Methods}

The study was conducted in the Dekar haor (naturally depressed seasonal-perennial open waterbody), one of the most important and largest haor of Bangladesh. The haor is surrounded by four Upazilas as Dakshin Sunamganj, Sunamganj sadar, Dowarabazar and Chhatak of Sunamganj district. It is situated by the side of Sylhet-Sunamganj high way and closed to Sunamganj district town. The study was conducted for a period of four months from 10 August to 8 December, 2016.

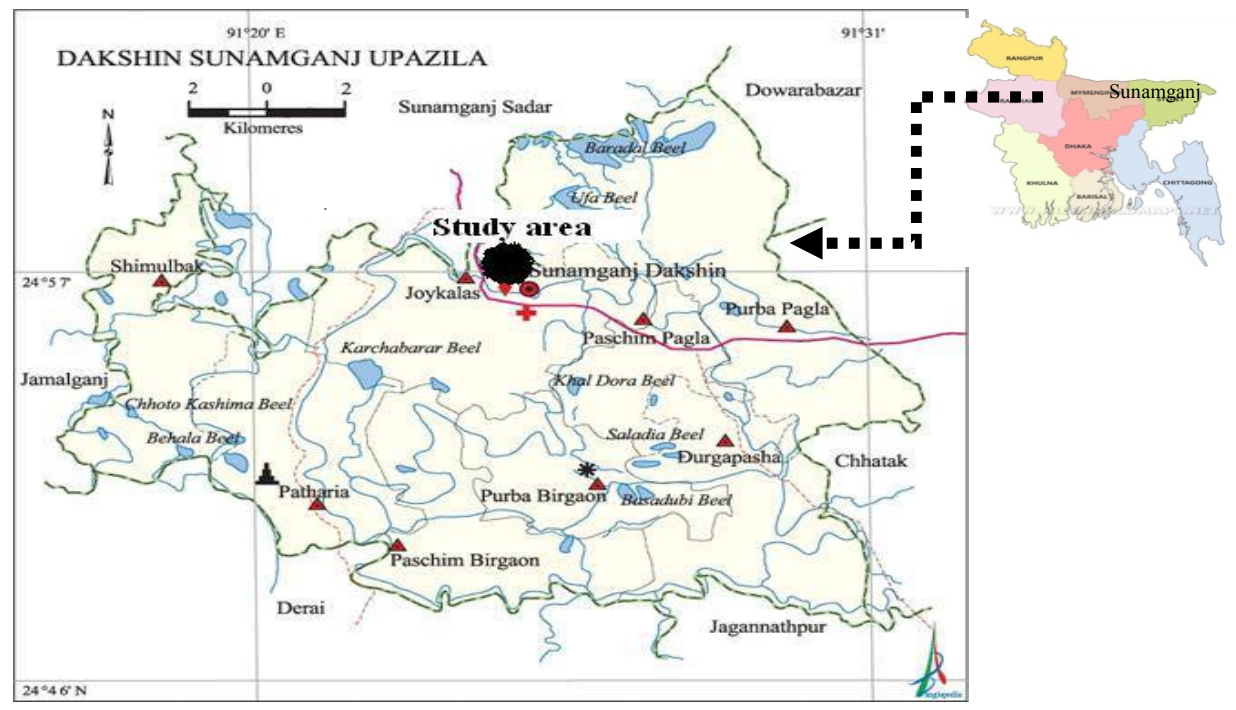

Fig. 1. A map showing the study area (Large black mark) in Dakshin Sunamganj Upazila.

Nine newly constructed floating nylon net cages $(3 \times 3 \times 1.5 \mathrm{~m})$ were set in the periphery of the haor. Frames of cages made by GI pipes and aluminium drums (250 litre) were used to float the cages in water. Wet cages were made of knot-less polyethylene net $($ mesh $1.0 \mathrm{~cm})$. Cages were hanged with cage frame. Bamboo made platform was set up over the cages and all cages were fixed with poles of the platform. Cages were installed at both sides of the platform for easily feed supply and intensive supervision. Open part of each cage was covered with another piece of nylon net (mesh $7-7.5 \mathrm{~cm}$ ) to avoid escaping of fish and predation by bird.

This study was a one factorial in which probiotics were the only experimental variable as $\mathrm{T}_{1}$ (brand a-biozyme), $\mathrm{T}_{2}$ (brand b-rapid grow), $\mathrm{T}_{3}$ (brand c-miracure) and $\mathrm{T}_{4}$ (control) having three replicates. The place selected for setting the cages was cleaned manually and 
limed with $\mathrm{CaO}$ at a rate of $0.025 \mathrm{~kg} / \mathrm{m}^{2}$. After five days of liming, all cages were stocked with required quantity of fry of male tilapia (O. niloticus) at a density of $35 \mathrm{no} . / \mathrm{m}^{3}$. Monosex tilapia fry were purchased from a private hatchery and was transported in oxygenated polythene bags from hatchery to experimental area. Before stocking, fry were acclimatized to the cage water for one hour period. Initial weight and length of 30 fishes were recorded before stocking in cages.

Stocked fry of tilapia were fed with commercial mega floating feed at a decreasing rate of $10-5 \%$ of body weight thrice daily until the previous day of harvest. Proximate compositions as moisture, crude protein, crude lipid, ash, crude fiber, carbohydrate of supplemented feed were $11,30,7,15,8$ and $29 \%$, respectively. The total daily feed ration was divided into three equal portions and was applied in the morning between $8.00-9.00$ a.m. in noon $12.00-1.00$ p.m. and in evening $5.0-6.00$ p.m. Feeding rates were adjusted every 15 days intervals depending on the body weight of stocked tilapia. Net of the cages were cleaned and checked every 15 days intervals. Behavior of tilapia was regularly observed specially after providing feed in the morning and in the evening to determine their conditions as movement and diseases.

Water quality parameters like surface temperature, transparency, dissolved oxygen (DO) concentration, $\mathrm{pH}$, total alkalinity and ammonia were determined at fortnightly intervals between 9 and 10 a.m. at the time of fingerlings sampling. Surface water temperature was measured on the spot using a standard centigrade thermometer. Transparency was recorded using Secchi disc. Dissolved oxygen was determined using a portable DO meter (YSI digital DO meter, Model 58, HANNA Company, America). $\mathrm{pH}$ of cage water was recorded using $\mathrm{pH}$ meter (HANNA Company, America). Total alkalinity was measured by titrimetric method (APHA 2000). Ammonia nitrogen was measured using ammonia test kit (Biosol, A.A. Biotech PVT LTD., Fishtech BD LTD).

Fortnightly sampling was done to determine growth of tilapia fry and to adjust the feed rations. Growth was measured regarding weight $(\mathrm{g})$ with digital balance and length by measuring scale.

Tilapias were totally harvested after 120 days of culture. They were caught using hand scoop net and lifting all cages from water on the same day. After harvest, all tilapia of cages were counted and weighed individually to determine survival rate, growth and yield. Specific growth rates (SGR), food conversion ratio (FCR), protein efficiency ratio (PER) and survival rate (\%) were calculated following the equation as cited by Pechsiri and Yakupitiyage (2005). The equations are as follows:

Weight gain $=$ Mean final weight - mean initial weight

Survival rate $(\%)=($ Number of fish harvested $\div$ total number of fish stocked $) \times 100$ 
$\operatorname{SGR}(\% /$ day $)=\{\operatorname{Ln}($ final body weight $)-\operatorname{Ln}($ initial body weight $) \times 100\} /$ cultured
period.

Protein efficiency ratio $($ PER $)=$ Weight gain $(\mathrm{g}) /$ protein consumed $(\mathrm{g})$

Feed conversion ratio $(\mathrm{FCR})=$ Feed consumed $(\mathrm{g}$ dry weight $) /$ live weight gain $(\mathrm{g}$ wet weight) of fish

Yield of fish $=$ No. of fish caught $\times$ (average final weight of fish - average initial weight fish)

Economic analyses of the different treatments was reckoned on the basis of purchasing prices of tilapia fry, feed, fertilizer, lime, transport cost and revenue from the sale of harvested tilapia. At the end of the study, all fish were sold at local market. Tilapia was sold at a rate of $\mathrm{Tk} .120 .0 / \mathrm{kg}$. Net profit and cost-benefit ratio (BCR) were calculated using the following formula:

$$
\begin{gathered}
\text { Net profit }=\text { Total return }- \text { total cost } \\
\text { BCR }=\text { Total return } / \text { total cost }
\end{gathered}
$$

Survival rate, growth and yield variables were analyzed using one way analysis of variance (ANOVA) to compare the treatments means. If the main effect showed significant, the ANOVA was followed by Duncan's Multiple Range Test (DMRT) (Zar 1984). All ANOVA were tested at 5\% level of significance using SPSS (Statistical Package for Social Science) version 20.

\section{Results and Discussion}

Final weight of tilapia was the highest in $\mathrm{T}_{3}(307.33 \mathrm{~g})$ followed by $\mathrm{T}_{2}(238.5 \mathrm{~g}), \mathrm{T}_{1}$ $(216.33 \mathrm{~g})$ and $\mathrm{T}_{4}(175.07 \mathrm{~g})$, respectively (Table 1 and Fig. 2). These results of the present study are consistent with the findings of Ahmed et al. (2014), who found final weight of tilapia as $207.90-271.48 \mathrm{~g}$ at $50 / \mathrm{m}^{3}$ densities over 120 days rearing in suspended cages fed commercial diet supplemented with probiotics at Dakatia river, Chandpur, Bangladesh. Begum et al. (2017) also demonstrated final weight of tilapia attained from 202.45 - $275.88 \mathrm{~g}$ for 120 days reared in net cages supplied floating feed with probiotics at a pond of Sylhet Agricultural University (SAU), Bangladesh, which is comparatively lower than the findings of the present study.

Daily weight gain of monosex tilapia in the present study was recorded from $1.34-2.42 \mathrm{~g}$ by rearing for 120 days at 35 no. $/ \mathrm{m}^{3}$ density and supplemented with floating feed. Ahmed et al. (2014) calculated daily weight gain of 1.45 - $1.98 \mathrm{~g}$ using commercial floated feed with probiotics in cages at Dakatia river and Begum et al. (2017) reported daily weight gain of monosex tilapia attained from $1.69-2.30 \mathrm{~g}$ for 120 days reared in net cages 
supplied floating feed with probiotics at a pond of SAU. So daily weight gain of tilapia in the present study is similar with the findings of above mentioned researchers.

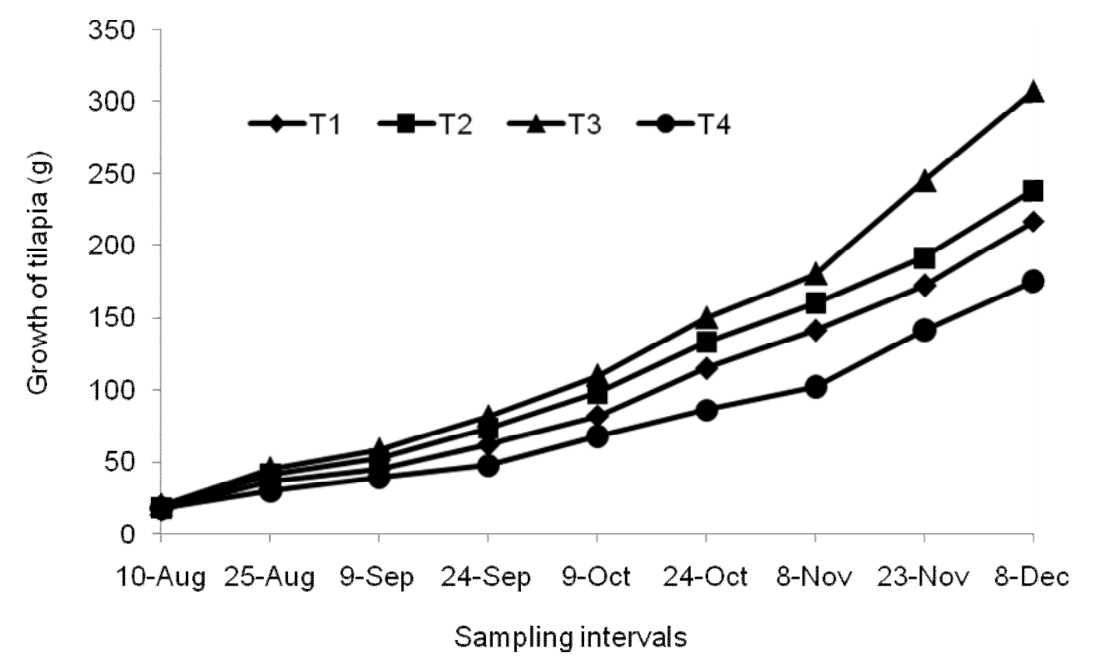

Fig. 2. Growth rate of tilapia (O. niloticus) under four treatments in haor environment.

In the present investigation, food conversion ratio (FCR) of tilapia ranged between 1.16 and 1.63 (Table 1). During the study period the FCR in four treatments were 1.31, 1.20, 1.16 and 1.63 in $\mathrm{T}_{1}, \mathrm{~T}_{2}, \mathrm{~T}_{3}$ and $\mathrm{T}_{4}$, respectively. The findings of the present study are coincided with the findings of Dev (2015), Ahmed et al. (2014) and Begum et al. (2017), who recorded FCR of tilapia in cage culture as 1.18 to $1.25,1.11$ to 1.41 and 1.01 to 1.38 , respectively. Significantly higher protein efficiency ratio (PER) of tilapia was found in $\mathrm{T}_{3}$ (2.87) compared to $\mathrm{T}_{4}(2.05), \mathrm{T}_{1}$ (2.55) and $\mathrm{T}_{2}$ (2.78), respectively. The observed PER values are in agreement with the findings of Begum et al. (2017), who recorded PER 2.26-3.10 in cage culture.

Specific growth rate (SGR) of tilapia varied from $2.09-2.43 \%$. SGR was comparatively higher in $\mathrm{T}_{3}(2.43 \%)$ than those of $\mathrm{T}_{2}(2.29 \%), \mathrm{T}_{1}(2.15 \%)$ and $\mathrm{T}_{4}(2.09 \%)$, respectively (Table 1). The observed SGR values are higher than the findings of Ahmed et al. (2014), who recorded 1.52 - 1.74\% in Dakatia river. In earthen pond, Diana et al. (1996) recorded SGR of $O$. niloticus as 3.10\% using feed and fertilizer in Thailand and Ahmed et al. (2013) reported SGR of monosex tilapia as 3.09\% using prepared feed $(55.24 \%$ protein). These findings are higher than that of the present study. 
Table 1. Growth, survival rate and yield (mean $\pm \mathrm{SD}$ ) of Oreochromis niloticus (monosex) in different treatments with probiotics.

\begin{tabular}{|c|c|c|c|c|}
\hline \multirow[b]{2}{*}{ Parameters } & \multicolumn{4}{|c|}{ Treatments } \\
\hline & $\begin{array}{c}\mathrm{T}_{1} \\
\text { (Brand a) }\end{array}$ & $\begin{array}{c}\mathrm{T}_{2} \\
\text { (Brand b) }\end{array}$ & $\begin{array}{c}\mathrm{T}_{3} \\
\text { (Brand c) }\end{array}$ & $\begin{array}{c}\mathrm{T}_{4} \\
\text { (Control) }\end{array}$ \\
\hline Stocking density $\left(\right.$ nos. $\left./ \mathrm{m}^{3}\right)$ & 35 & 35 & 35 & 35 \\
\hline Average initial weight (g) & $16.33 \pm 3.15$ & $15.33 \pm 2.75$ & $16.66 \pm 3.48$ & $14.33 \pm 6.41$ \\
\hline Average final weight (g) & $216.33^{\mathrm{c}} \pm 7.52$ & $238.5^{\mathbf{b}} \pm 11.19$ & $307.33^{\mathrm{a}} \pm 33.92$ & $175.07^{\mathrm{d}} \pm 18.66$ \\
\hline Daily weight gain (g) & 1.67 & 1.86 & 2.42 & 1.34 \\
\hline FCR & $1.3^{\mathbf{b}}$ & $1.20^{\mathbf{b c}}$ & $1.16^{\mathrm{c}}$ & $1.63^{\mathrm{a}}$ \\
\hline PER & 2.55 & 2.78 & 2.87 & 2.05 \\
\hline Survival rate $(\%)$ & $91.9^{\mathbf{b}} \pm 3.72$ & $97.1^{\mathrm{a}} \pm 5.57$ & $97.6^{\mathrm{a}} \pm 4.90$ & $91.4^{\mathbf{b}} \pm 2.95$ \\
\hline Specific growth rate $(\% /$ day $)$ & $2.15^{\mathrm{c}}$ & $2.29^{\mathrm{b}}$ & $2.43^{\mathrm{a}}$ & $2.09^{\mathrm{d}}$ \\
\hline Yield $\left(\mathrm{kg} / \mathrm{m}^{3}\right)$ & $6.95^{\mathbf{c}} \pm 0.88$ & $8.10^{\mathbf{b}} \pm 1.08$ & $10.5^{\mathrm{a}} \pm 1.15$ & $5.60^{d} \pm 0.71$ \\
\hline
\end{tabular}

Mean values in the same row with same superscript letters are not significantly different $(\mathrm{p}>0.05)$.

Survival rate of male tilapia in this study was $91.4-97.6 \%$ (Table 1). Higher survival of tilapia was found in $\mathrm{T}_{3}(97.60 \%)$ followed by $\mathrm{T}_{2}(97.10 \%), \mathrm{T}_{1}(91.90 \%)$ and $\mathrm{T}_{4}(91.40 \%)$. Survival rate of caged tilapia ranged from 95.76 - 97.54\% (Ahmed et al. 2014) and from 95.39 - 95.87\% (Dev 2015), which are comparable to that of present study. Begum et al. (2017) obtained the survival rate of tilapia in cage culture as $89.52-91.43 \%$, which is slightly lower than the present findings.

Yield of tilapia obtained from all treatments ranged from $5.60-10.5 \mathrm{~kg} / \mathrm{m}^{3}$ with the highest yield $\left(10.5 \mathrm{~kg} / \mathrm{m}^{3}\right)$ in $\mathrm{T}_{3}$ and the lowest yield $\left(5.60 \mathrm{~kg} / \mathrm{m}^{3}\right)$ in $\mathrm{T}_{4}$ (Table 1$)$. The observed yield was higher than the findings of Begum et al. (2017), who recorded 6.35 $8.82 \mathrm{~kg} / \mathrm{m}^{3}$ in a freshwater pond. But the finding of the present study is slightly lower than the finding of Moniruzzaman et al. (2015), who obtained $12.4 \mathrm{~kg} / \mathrm{m}^{3}$ tilapia production from cages at $50 / \mathrm{m}^{3}$ densities at Kaptai lake.

Profit of tilapia farming in the present study was the highest (TK.798.96 $\left.\pm 90.85 / \mathrm{m}^{3}\right)$ in $\mathrm{T}_{3}$ followed by $\mathrm{T}_{2}\left(\mathrm{TK} .565 .63 \pm 94.0 / \mathrm{m}^{3}\right), \mathrm{T}_{1}\left(\mathrm{TK} .433 .26 \pm 39.9 / \mathrm{m}^{3}\right)$ and $\mathrm{T}_{4}(\mathrm{TK} .298 .22$ $\pm 80.7 / \mathrm{m}^{3}$ ). The lowest profit (TK.298.22 $\pm 80.7 / \mathrm{m}^{3}$ ) was found in controlled treatment (without probiotics, $\mathrm{T}_{4}$ ) (Fig. 3). Benefit cost ratio (BCR) was also highest in $\mathrm{T}_{3}(2.90)$ followed by $\mathrm{T}_{2}(2.39), \mathrm{T}_{1}(2.08)$ and $\mathrm{T}_{4}(1.79)$ indicating that highest benefit was obtained from the treatment of brand c probiotics $\left(\mathrm{T}_{3}\right)$ since it contains three beneficial bacteria and utilize supplied feed very efficiently. So it may be concluded that brand c probiotics $\left(\mathrm{T}_{3}\right)$ is better among four treatments in respect of survival rate, growth and fish yield. 


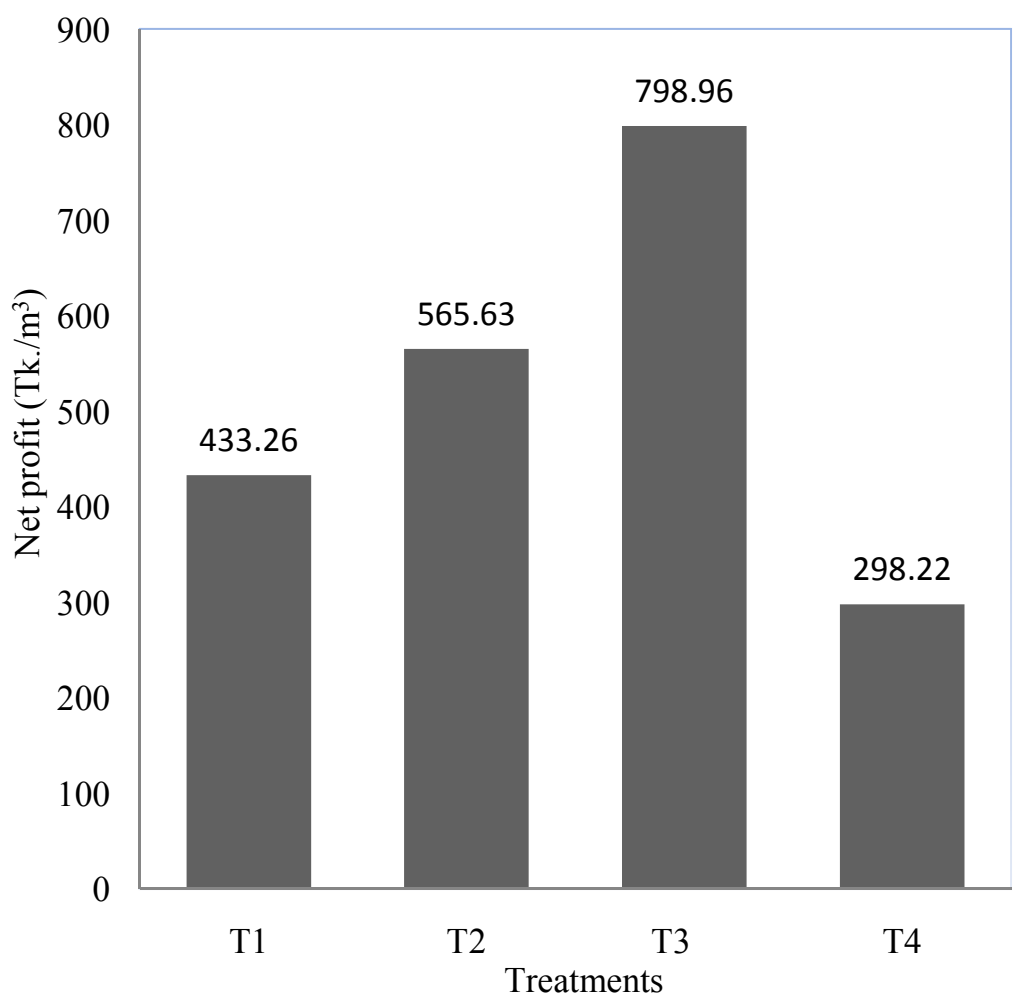

Fig. 3. Net profit of tilapia farming under four treatments in Dekar haor.

Table 2. Water quality parameters (mean \pm SD) recorded from cages under different treatments during the study period of August- December 2016.

\begin{tabular}{lllll}
\hline \multirow{2}{*}{ Parameters } & \multicolumn{4}{c}{ Treatments } \\
\cline { 2 - 5 } & \multicolumn{1}{c}{$\mathrm{T}_{1}($ Brand a) } & \multicolumn{1}{c}{$\mathrm{T}_{2}($ Brand b) } & \multicolumn{1}{c}{$\mathrm{T}_{3}($ Brand c) } & \multicolumn{1}{c}{$\mathrm{T}_{4}($ Control $)$} \\
\hline Temperature $(\mathrm{C})$ & $29 \pm 1.8$ & $29.1 \pm 1.9$ & $28.9 \pm 1.8$ & $28.7 \pm 1.9$ \\
Transparency $(\mathrm{cm})$ & $35.23 \pm 1.48$ & $34.17 \pm 1.25$ & $33.34 \pm 1.52$ & $36.24 \pm 1.31$ \\
Dissolved Oxygen $(\mathrm{mg} / \mathrm{l})$ & $6.49 \pm 0.81$ & $6.68 \pm 0.79$ & $6.88 \pm 0.80$ & $6.11 \pm 0.75$ \\
$\mathrm{pH}$ & $6.85(7.0-7.5)$ & $6.73(7.0-7.4)$ & $6.50(7.0-7.4)$ & $7.02(7.0-7.4)$ \\
Total alkalinity $(\mathrm{mg} / \mathrm{l})$ & $118.10 \pm 5.62$ & $122.11 \pm 4.70$ & $127.20 \pm 6.60$ & $121.12 \pm 5.40$ \\
$\mathrm{NH}_{3}-\mathrm{N}(\mathrm{mg} / \mathrm{l})$ & $0.09 \pm 0.002$ & $0.05 \pm 0.001$ & $0.01 \pm 0.002$ & $0.10 \pm 0.005$ \\
\hline
\end{tabular}

Environmental parameters (water temperature, transparency, dissolved oxygen, $\mathrm{pH}$, alkalinity and ammonia) of the study are presented in Table 2. Values of water temperature in the present study were $28.7-29.1^{\circ} \mathrm{C}$. Begum et al. (2017) and Dev (2015) 
recorded the temperature of a pond in SAU campus as $26.8-30.9$ and $28.5^{\circ} \mathrm{C}$, respectively. These findings are similar to the findings of the present study. Water transparency in the study ranged from $33.34-36.24 \mathrm{~cm}$. The finding of present study is similar with the findings of Begum et al. (2017) and Dev (2015), who recorded transparency of $30.0-40.9 \mathrm{~cm}$ and $30-40 \mathrm{~cm}$, respectively. Concentrations of dissolved oxygen of the study were 6.11 to $6.88 \mathrm{mg} / \mathrm{l}$, which is similar to the findings of Begum et al. (2017) and Dev (2015), who recorded dissolved oxygen as $4.5-6.1 \mathrm{mg} / \mathrm{l}$ and 5.25 $\mathrm{mg} / \mathrm{l}$, respectively at SAU ponds. Water $\mathrm{pH}$ of this study varied from $6.5-7.02$. The findings of the present study are in agreement with the $\mathrm{pH}$ values of $7.0-7.5$ obtained by Begum et al. (2017). Values of total alkalinity were in the range of $118.10-127.20 \mathrm{mg} / \mathrm{l}$ in all cages. Begum et al. (2017) recorded total alkalinity were ranging from 80.0-85.7 $\mathrm{mg} / \mathrm{l}$ in cages in SAU pond. Mairs (1966) stated that waterbodies having alkalinity 40 ppm or more are considered more productive than waterbodies of lower alkalinity. So the findings of the present study are within suitable ranges. Concentrations of ammonia nitrogen in all treatments varied between 0.01 and $0.10 \mathrm{mg} / \mathrm{l}$. Begum et al. (2017) recorded $0.018 \mathrm{mg} / 1$ ammonia concentration in the SAU research pond. Meade (1985) stated that the permissible level is higher than the value of $0.012 \mathrm{mg} / 1 \mathrm{commonly}$ accepted by fish culturists. Ammonia values of the present study were within the accepted level ( $>0.012 \mathrm{mg} / \mathrm{l})$.

Open waterbodies are directly/indirectly connected with one another. There is a great scope to introduce tilapia cage farming in the open waterbodies without disturbing the water environment. Introduction of tilapia cage culture system in the open waterbodies can enhance the fish yield to a significant level. Results of the study imply that brand c probiotics $\left(\mathrm{T}_{3}\right)$ is better among four treatments from the viewpoint of survival rate, growth, yield and economic benefit. Therefore, it may be suggested to apply probiotics in tilapia cage farming in open/perennial waterbodies for increasing fish production with high profit.

\section{Acknowledgements}

The present study was conducted under financial support by Krishi Gobeshona Foundation (KGF), BARC, Farm Gate, Dhaka, Bangladesh. Authors also acknowledge the Fishtech BD Ltd., Sylhet Office for providing three brands of probiotics.

\section{References}

Ahmed, G.U., N. Sultana, M. Shamsuddin and M.B. Hossain. 2013. Growth and production performance of monosex tilapia (Oreochromis niloticus) fed with homemade feed in earthen mini ponds. Pakistan Journal of Biological Science. 16(23): 1781-1785.

Ahmed, T., S.J. Hasan, M.R.A. Hossain, I. Haidar, A.K.M.S.A. Rubel and M.H. Pramanik. 2014. Assessment on impact of dietary probiotic supplementation on growth indices of monosex 
tilapia (Oreochromis niloticus) cage culture at Dhakatia river, Chandpur, Bangladesh. World Journal of Fish and Marine Sciences 6(5): 441-446.

APHA (American Public Health Association). 2000. Standard methods for the examination of water and waste water. $18^{\text {th }}$ ed., APHA, Washington, D. C.

Balcazar, J., A. Aguirre, G. Gomez and W. Paredes. 2006. Culture of hybrid Red tilapia (Oreochromis mossambicus $\times$ Oreochromis niloticus) in marine cages: Effects of stocking density on survival and growth. University of Zaragoza, Zaragoza, Spain.

Ballarin, J.D. and R.D. Hallar. 1982. The intensive culture of tilapia in tanks, raceway \& cages. Recent advanced in aquaculture, West view press, Boulder, Colorado, USA. pp. 265-355.

Begum, N., M.S. Islam, A.K.M.F. Haque and I.N. Suravi. 2017. Growth and yield of monosex tilapia (Oreochromis niloticus) in floating cages fed commercial diet supplemented with probiotics in freshwater pond, Sylhet. Bangladesh Journal of Zoology 45(1): 27-36.

Beveridge, M.C.M. 1987. Cage aquaculture. Fishing News Books Ltd. Farnhan, Surrey, England.

Dev, A.R. 2015. Comparison of production performance and economics between mono-sex and mixed-sex tilapia (Oreochromis niloticus), MS Thesis, Department of Aquatic Resource Management, Faculty of Fisheries, SAU, Sylhet. pp. 48-51.

Diana, J.S., C.K. Lin and Y. Yi. 1996. Timing of supplemental feeding for tilapia production. Journal of the World Aquaculture Society 27: 410-419.

DoF (Department of Fisheries). 2017. National Fish Week Compendium (in Bengali). Ministry of Fisheries and Livestock, Dhaka, Bangladesh. 160pp.

FAO (Food and Agriculture Organization). 2004. Fish Stat Plus. Aquaculture Production 19502002.

Fitzsimmons, K. 2004. Development of new products and markets for the global tilapia trade. In: Bolivar, R., G.Mair and K. Fitzsimmonas (Editors), Proceeding of the $6^{\text {th }}$ International Symposium on Tilapia in Aquaculture, Manila, Philippines. pp. 624-633.

Gatesoupe, F.J. 1999. The use of probiotics in aquaculture. Aquaculture 180: 147-165.

Geovanny, G.R., B.J. Luis and M. Shen. 2007. Probiotics as control agents in aquaculture. Journal of Ocean University of China 6(1): 76-79.

Hussain, M.G. 2004. Farming of tilapia: Breeding plans, mass seed production and aquaculture techniques. 149pp.

Islam, M.L., H.K. Pal and M.J. Alam. 2008. Effectiveness of commercial probiotics as a biotechnological tool for shrimp (Penaeus monodon) health management. Project Completion Report, Bangladesh Fisheries Research Institute, Brackishwater Station, Paikgacha, Khulna, Bangladesh. 15pp.

Mairs, D.F. 1966. A total alkalinity atlas for marine lake waters. Limnological Oceanography 11: $68-72$.

Meade, J.W. 1985. Allowable ammonia for fish culture. Prog. Fish Cult. 47: 135-145.

Moniruzzaman, M., K.B. Uddin, S. Basak, Y. Mahmud, M. Zaher and S.C. Bai. 2015. Effects of stocking density on growth, body composition, yield and economic returns of monosex tilapia (Oreochromis niloticus) under cage culture system in Kaptai lake of Bangladesh. Journal of Aquaculture Research and Development 6: 4-7.

MPHA (Master Plan of Haor Areas). 2012. Ministry of Water Resources. Government of Peoples Republic of Bangladesh. Volume 1, Summary Report, April 2012.

Ponzoni, R.W., A. Hamzah, T. Saadiah and N. Kamaruzzaman. 2005. Genetic parameters and response to selection for live weight in the GIFT strain of Nile tilapia (Oreochromis niloticus). Aquaculture 247: 203-210.

Pechsiri, J., A. Yakupitiyage. 2005. A comparative study of growth and feed utilization efficiency of sex-reversed diploid and triploid Nile tilapia (Orechromis niloticus L.). Aquaculture Research 36: 45-51.

Zar, H. 1984. Biostatistical Analysis. Printice Hall Inc, Englewood Clifts. New Jersey, 592. pp. 